\title{
らい性結節性縕玟（ENL）に対する サリドマイド診㙩ガイドライン
}

\author{
石井則久 ${ }^{* 1)}$ 、石田 裕 $^{2)}$ 、岡野美子 ${ }^{3)}$ 、尾崎元昭 ${ }^{4)}$ 、儀同政一 ${ }^{1)} 、$ \\ 熊野公子 ${ }^{5)}$ 、後藤正道 ${ }^{6)}$ 、野上玲子 ${ }^{7)}$ 、畑野研太郎 ${ }^{3)}$ 、山田 暁 $^{8)}$ 、四津里英 ${ }^{9)}$ \\ 1 ）国立感染症研究所ハンセン病研究センター、2）天草市立牛深市民病院 \\ 3）国立療養所邑久光明園、4）京都大学医学部皮膚科、5）兵庫県立がんセンター \\ 6 ）国立療養所星塚敬愛園、7）国立療養所菊池恵楓園、8）国立駿河療養所 \\ 9) 国立国際医療研究センター
}

〔受付：2011 年 4 月 13 日、掲載決定：2011 年 4 月 25 日〕

キーワード：ガイドライン、サリドマイド、ハンセン病、2 型らい反応（らい性結節性紅斑）、TERMS ${ }^{\circledR}$

ハンセン病の急性症状としての 2 型らい反応 (らい性結節性紅斑、 erythema nodosum leprosum: ENL) の治療薬としてサリドマイドがある。日本においては多発性骨髄腫に保険適用になっている。使用にはサ リドマイド製剤安全管理手順（Thalidomide Education and Risk Management System: TERMS ${ }^{\circledast}$ ) を適正に 遵守することになっている。

今回サリドマイドを 2 型らい反応に使用するにあたって診療ガイドラインを作成した。2 型らい反応に 対してのサリドマイド使用の経験や文献は多くない。そのため、TERMS ${ }^{\oplus}$ を適正に遵守し、サリドマイド を就寝前に 50 〜 100mg 内服から開始し、症状の変化を観察しながら増減することで2型らい反応をコン トロールすることとした。

\section{はじめに}

ハンセン病は、わが国においては、1996 年にら い予防法が廃止されたのにともない、保険診療に

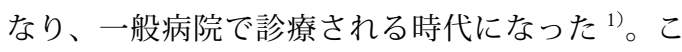
のためハンセン病の診療中に生じることの多い反 応である 2 型らい反応の診療も一般医療機関で行

\footnotetext{
* Corresponding author: 国立感染症研究所ハンセン病研究センター 干 189-0002 東京都東村山市青葉町 4-2-1 TEL : 042-202-6003 FAX : 042-391-8210 E-mail : norishii@nih.go.jp
}

うことになった。その治療として世界的視野で現 時点で有用と考えられるサリドマイドの適正使用 についてのガイドラインが必要であり、ここに作 成するにいたった。

なお 2 型らい反応の病態が全て解明されてはい ない現状で、またサリドマイドの使用経験も少な く、治験が実施されていない状況から、個々の症 例の診療内容は診療に当たる医師が症例毎の事情 を踏まえて組み立てるべきものであって、その 内容が本ガイドラインに記載されていない診療 を含むことを阻むものではない。しかし、サリド マイドの使用には「サリドマイド製剂安全管理手 順 (Thalidomide Education and Risk Management 


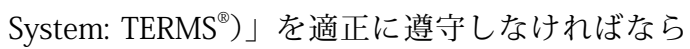
ない。さらにサリドマイドの薬害の歴史を教訓と して、サリドマイドを使用する医師は本ガイドラ インの最後に記載した「サリドマイド被害者から のメッセージ」を必ず読むべきである。

\section{1 ） ハンセン病とらい反応}

ハンセン病はMycobacterium leprae による慢 性抗酸菌感染症である。しかし、病気の経過中に 急性の炎症症状を呈することがあり、らい反応 (lepra reaction) と呼ばれている ${ }^{2)}$ 。らい反応に は 1 型らい反応（type 1 reaction, 同義語として境 界反応 borderline reaction, あるいはリバーサル反 応 reversal reaction）と、2 型らい反応（type 2 reaction, 同義語としてらい性結節性紅斑 erythema nodosum leprosum: ENL）がある。1 型らい反応 は細胞性免疫反応を主体としたものであり、2 型 らい反応は抗原抗体反応を主体としたものである。 両者のらい反応は、年余にわたることがあり、未 梢神経障害やそれに続く後遺症、視力障害と深く 関係するので、早期に診断し適切な治療をおこな う必要がある。

\section{2) サリドマイドについて}

分子式は $\mathrm{C}_{13} \mathrm{H}_{10} \mathrm{~N}_{2} \mathrm{O}_{4}$ 、化学名は 2-[(3RS)-2,6dioxopiperidin-3-yl]isoindoline-1,3-dione である。 サリドマイド（thalidomide）は、1953 年にス イスで合成され、1957 年から西ドイツで睡眠剤、 精神安定剂として販売が開始された。1958 年にわ が国でも発売された。

1961 年に、妊娠初期にサリドマイドを服用する と、新生児に重い先天異常を引き起こすことが明 らかとなり、11月に西ドイツのグリュネンタール 社が製品の回収を開始した。日本では 1962 年の 9 月に販売停止と製品の回収を開始したが、一部 の製剤はその後も市中で出回っていた。日本での サリドマイドによる被害者は 309 人とされている 3)。なお、米国では、1960年に販売許可の申請があっ たが、FDAのケルシー審査官が安全性に疑問を抱 き、最終的に許可されなかった。

一方、たまたまハンセン病の 2 型らい反応をも つ患者がサリドマイドを服用したところ、その症 状が治癒したことから、サリドマイドはハンセン 病の 2 型らい反応に特異的に効果を示すことがわ

表 1 アメリカ合衆国におけるサリドマイドの 2 型らい反応（ENL）に対する承認状況

\begin{tabular}{|c|c|}
\hline 効能 - 効果 & $\begin{array}{l}\text { 中程度から重度の ENL の皮膚症状に対する急性期治療に適応される。 } \\
\text { 中程度から重度の神経炎を伴う ENLに対する単独治療としての適応は } \\
\text { ない。ENL 再発時の皮膚症状の予防及び抑制のための維持療法としても } \\
\text { 適応される。 }\end{array}$ \\
\hline 用法 - 用量 & 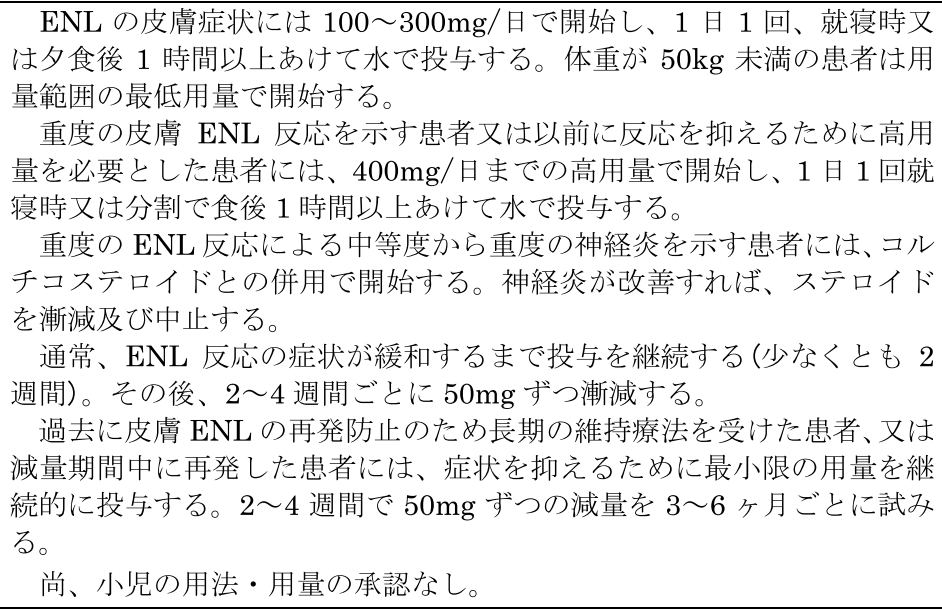 \\
\hline 承認年月 & 1998 年 7 月 \\
\hline
\end{tabular}


かってきた ${ }^{4)}$ 。その後、1998 年にハンセン病の 2

型らい反応に対する治療薬として、米国で承認さ
れた（表 1)。その後オーストラリアやニュージー ランドなどでも、その承認が追随されてきている。

表 2 2型らい反応（ENL）に対するサリドマイド使用文献

\begin{tabular}{|c|c|c|c|c|c|c|c|c|c|c|}
\hline $\begin{array}{l}\text { 茂献 } \\
\text { 臬号 }\end{array}$ & 試験の種類 & 被験者数 & 対象患者 & 試験藥,対照藥 & 併用藥 & 用法·用量 & 投与期間 & 評価方法 & 有効性の結果 & 安全性の結果 \\
\hline 6 & 二重盲検試験 & $\begin{array}{l}12 \text { 例(男11例。 } \\
\text { 閉経後女1例) }\end{array}$ & 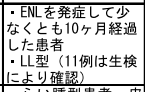 & $\begin{array}{l}\text { THA 錠, } \\
\text { ブラセボ }\end{array}$ & $\begin{array}{l}\text { PSL, スチボフェ } \\
\text { ン及びパラセタ } \\
\text { モールは服用可 } \\
\text { 能 } \\
\end{array}$ & $\begin{array}{l}\text { 1日3回各100mg 投与。但 } \\
\text { し, 体重が35kg以の場 } \\
\text { は1日回各100mgを投与。 }\end{array}$ & $\begin{array}{l}6 \text { 週間投与後, THA } \\
\text { とプラセボを入 } \\
\text { れ替えてさらに6 } \\
\text { 週間投与 }\end{array}$ & 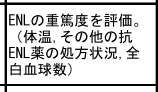 & 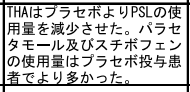 & 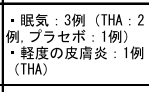 \\
\hline 7 & 二重盲㛟試馱 & $\begin{array}{l}\text { 52例（男37例 } \\
\text { 女15例: } 17-58 \\
\text { 歳) }\end{array}$ & 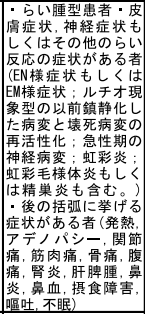 & THA, プラセボ & 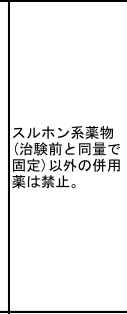 & 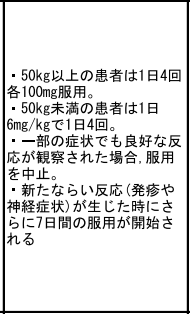 & 7-28日間 & & 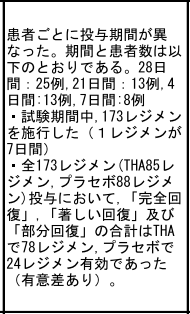 & 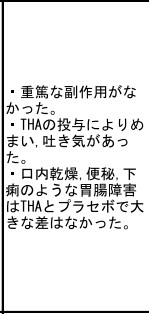 \\
\hline 8 & 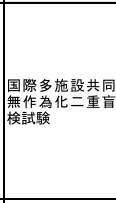 & $\begin{array}{l}92 \text { 例 (男; } 15 \text { 歳 } \\
\text { 以上) }\end{array}$ & 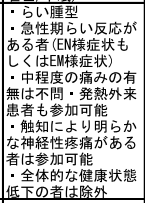 & 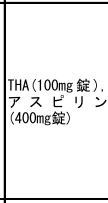 & 全て整止 & 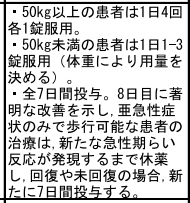 & 7-28日間 & 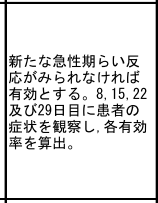 & 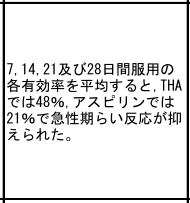 & 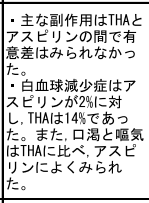 \\
\hline 9 & \begin{tabular}{|} 
立重言榙試験。 \\
比較試験
\end{tabular} & 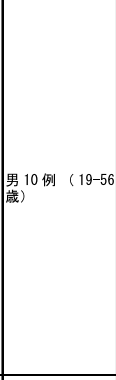 & 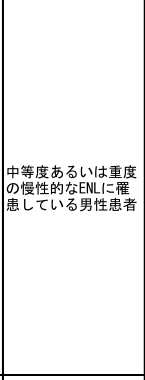 & $\begin{array}{l}\text { THA (100mg 錠), } \\
\text { ブラセボ }\end{array}$ & 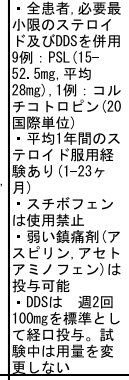 & $\begin{array}{l}16 \text { 週間及び24週間の2種類 } \\
\text { の試験が行われた。 }\end{array}$ & & 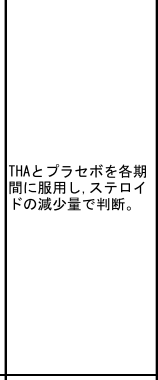 & 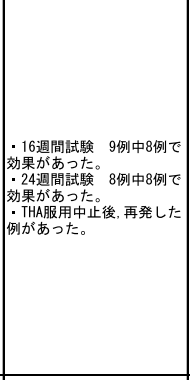 & 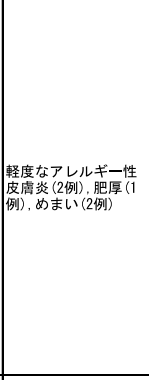 \\
\hline 10 & 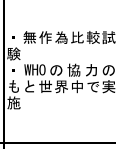 & 成人男72例 & $\begin{array}{l}\text { - LL型男性患者及び } \\
\text { 再発性LL型男性患煮 } \\
\text { 中等度 重度の患 } \\
\text { 者 }\end{array}$ & CLF, THA & & 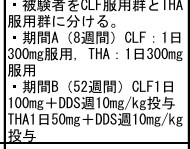 & & $\begin{array}{l}\text { ·い反応を評価。 } \\
\text { ·細菌学的な評価。 }\end{array}$ & 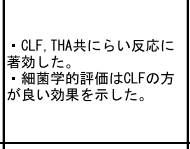 & \\
\hline 11 & \begin{tabular}{|l|} 
舞作為二重盲検 \\
試験
\end{tabular} & 22例 $(18-46$ & 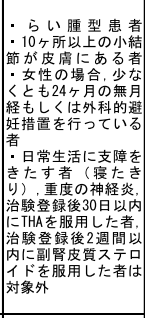 & 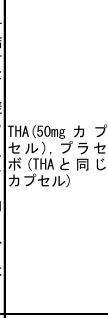 & 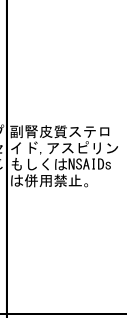 & 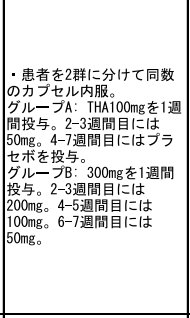 & & 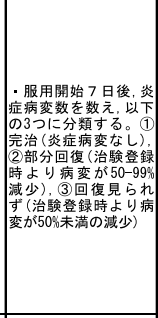 & 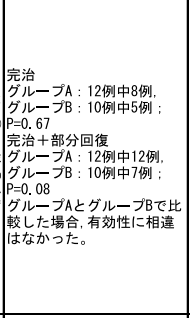 & 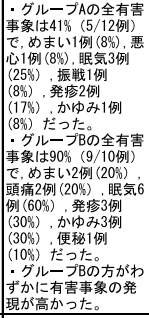 \\
\hline 12 & 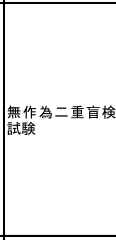 & 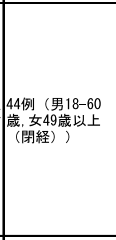 & 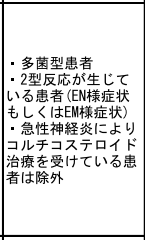 & ペントキぎ & & $\begin{array}{l}1 \text { 1日ペントキシフィリン } \\
\text { 1.2g，THA 300mgを投与。 }\end{array}$ & 30日間 & 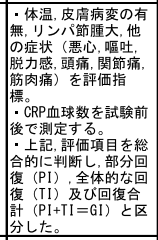 & 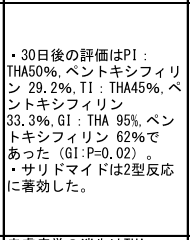 & 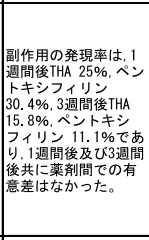 \\
\hline 13 & 無作為比較試験 & $\begin{array}{l}60 \text { 例 (男49例，女 } \\
11 \text { 例) }\end{array}$ & $\begin{array}{l}\text { ·MB患者 } \\
\text {-中䅅度から重度の } \\
\text { ENL患者 }\end{array}$ & THA錠，PSL & & 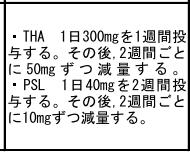 & & 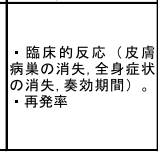 & 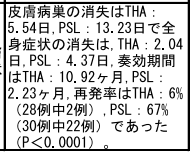 & 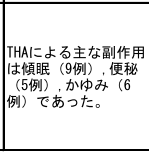 \\
\hline
\end{tabular}

CLF：クロファジミン， DDS: ダプソン， EN: 結節性紅斑， EM：多形紅斑， PSL：プレドニソロン， THA：サリドマイド， アスピリン: アセチルサリチル酸 
サリドマイドは、1998 年には多発性骨䯣腫にも 有効であることが報告され ${ }^{5)}$ 、わが国においても、 2008 年に多発性骨䯣腫に対して保険適応の承認を 受けた。しかしその使用にあたっては、催奇形性 作用があるので、薬剤の取り报いや服用患者の限 定を厳しく行っている。

\section{3）2型らい反応とサリドマイドに関する 有効性や安全性について}

現在のところ、前向き研究 (prospective study) は ないので、後ろ向き研究 (retrospective study) によ る結果を利用して決定することになる（表2） ${ }^{6-14) 。 ~}$

2型らい反応に対するサリドマイドの適応は、米 国で最初に承認された(表 1 )。ただし使用にあたつ ては、投与を担当する医師が、薬剤の安全性に関す る教育を受けることが条件になっている。米国では System for Thalidomide Education and Prescribing Safety（S. T. E. P. S. ${ }^{\circledR}$ ) として ${ }^{15)}$ 、日本ではサリド マイド製剤安全管理手順（Thalidomide Education and Risk Management System: TERMS ${ }^{\oplus}$; 藤本製薬

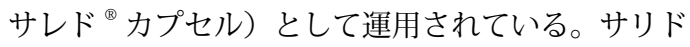
マイドには妊娠初期に内服すると明らかな催奇形 性作用があるので、妊婦には絶対禁忌である。妊 娠可能な年齢の女性には妊娠検査で陰性を確認し、 男性には確実に避妊させ、これらの点についてあら かじめ文書で同意を得ておく。また保管管理上、譲 渡は不可である。

わが国では、国立ハンセン病療養所施設長協議 会で、「サリドマイドの取り扱いに関するガイド ライン」（1999 年、2005 年一部改訂）を作成し、 各療養所所長の責任のもとに、同剤の保管管理に 係る規定に基づいて使用している。

\section{4） 2 型らい反応の診断}

\section{2型らい反応を生じる症例の特徵}

2型らい反応はハンセン病の多菌型（multibacillary type, MB, Ridley-Jopling 分類では LL 型と BL 型に相当する）の患者に生じる。MB 患者の中でも 高い菌指数 (bacterial index: BI) の患者に発生し やすい。ことに、ハンセン病の薬物治療開始数力 月後から生じることが多いが、治療の有無にかか
わらず、治療前、治療終了後にも発症することが ある。

\section{2 型らい反応の機序}

MB 患者ではらい菌抗原に対する細胞性免疫が十 分に作動しないため、菌が増殖を続ける。抗菌薬 治療あるいは菌自体の寿命によって菌体が破壊さ れ、菌体からの多量の抗原が組織や血流中に放出 される。その抗原に対する抗体が産生される。そ こで抗原抗体の免疫複合物が形成され、補体の活 性化を生じ、それらが組織や血管を障害するのが 2型らい反応である。

病理組織学的には、真皮および皮下脂肪織に多 数の好中球浸潤が認められる。蛍光抗体法で血管 壁に免疫複合物の沈着が証明されることがある。

\section{2型らい反応の臨床症状}

典型的な 2 型らい反応は、発熱を伴って発症す る。 $39 \sim 41^{\circ} \mathrm{C}$ 高熱、全身倦急、関節痛が生じる。 菌抗原のあるところでは、皮膚・神経・眼・リンパ節・ 関節・精巣などどこでも急性炎症を起こす。四肢・ 体幹に好発するが、顔面にも生じる ${ }^{2)}$ 。経過は年 余にわたることがある。

a. 皮膚症状：皮膚では発赤を伴う硬結を生じ、 ENL と呼ばれ、この名称が 2 型らい反応の代名詞 としても使われる。通常の結節性紅斑（erythema nodosum: EN）の皮疹は下肢に好発するが、ENL は小豆大から鶏卵大の圧痛を伴う硬結や隆起性紅 斑が一見正常の顔面、四肢、体幹など全身に生ずる。 個疹は数日で消退することが多いが次々と新生す る。重症の場合には水疱や膿瘍を形成し、さらに それらが自潰することがある。病理組織学的には 真皮から皮下脂肪織に多数の好中球の集積を認め る。血管壁に多核球が浸潤し壊死性血管炎を認め たり、免疫組織化学染色で免疫複合体が沈着した りすることもある。

b. 神経症状 : 末梢神経炎を起こし、耐え難い 疼痛に苦しめられることがある。とくに尺骨神経 に有痛性腫脹が起こりやすく、2 型らい反応の経 過中に手指変形を生じる例も少なくない。神経痛、 急速な感覚異常や運動障害、筋力低下、目立たな い形で徐々に起こる障害などへの注意が必要であ る。

c. 眼症状 : 眼では急性の虹彩毛様体炎、(上) 強膜炎を生じる。充血・眼痛・羞明・視力低下を来す。 
ENL を繰り返すと慢性虹彩毛様体炎を生じ、虹彩 癒着・小瞳孔・併発白内障・続発緑内障そして失 明にいたることもある。

d. 全身症状: 発熱、全身倦怠感、リンパ節腫脹、 手足の浮腫、関節痛、そのほかに精巣炎が随伴す ることがある。

\section{2 型らい反応の臨床検査所見}

末梢血の好中球数、血沈值、CRP、血清 TNF- $\alpha$

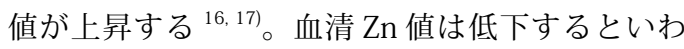
れている ${ }^{18)}$ 。CRP 值は 2 型らい反応の病勢をよく 反映する。

\section{2型らい反応の重症度}

症状によって軽症、重症に分けて治療の方針を 決める。

皮膚病変の ENL が主で、潰瘍もなく、浸潤性の 紅斑が多発する程度のみの場合は、軽症とする。 軽症では患者の日常生活に支障をきたすことはな い。

一方、皮膚病変の潰瘍化や、神経症状、眼症状、 発熱などの全身症状などが認められれば、重症と して扱う。これらの症状は患者の日常生活に支障 をきたす。また皮膚潰瘍は治癒しても㓔痕として 永く残存し、神経症状や眼症状は不可逆的な障害 を残す可能性がある。これらの点から、早期にか つ充分に治療しなければならない。とくに神経障 害を予防するように注意する。

重症度の判定に検査值で CRP 值も参考にできる が、とくに決まった基準值はない。

\section{5）２型らい反応の治療}

\section{1. 基本的な注意}

安静を守らせる。仕事、学業などは無理のない程 度に行う。飲酒をひかえ睡眠を十分にとる。多臓器 症状を呈する場合には、入院安静も考慮する ${ }^{2,19) 。 ~}$

\section{2. 軽症の場合}

軽症の場合は、特別の治療を必要としない。何 らかの自覚症状を訴える場合には、対症的に治療 を考慮する。たとえば疼痛に対して非ステロイド 性抗炎症薬 (non-steroid anti-inflammatory drugs: NSAIDs）や鎮静薬などを適宜投与する。

\section{3. 重症の場合}

重症の場合は、サリドマイドあるいはステロイ
ド内服薬の全身投与を行う。ただし、後述するよ うに、妊娠中の女性へのサリドマイド投与は絶対 禁忌である。さらに薬剤の管理を厳重に行う必要 があり、医師への教育が義務化されている。

a ．2 型らい反応のサリドマイドによる治療： サリドマイドは著効する ${ }^{6-14,20-24) 。 な お 、 サ リ ト ゙ マ ~}$ イドの使用に当たっては TERMS ${ }^{\circledast}$ を適正に遵守し なければならない。

サリドマイドの投与法としては、就寝前に 50 〜 100mg を内服する。有効である場合は、翌朝には 2 型らい反応の症状は軽快し始める。すなわち発 熱、皮膚の硬結、神経炎症状は非常に早く消退す る。サリドマイド内服により短時間で症状の軽快 を見ることが 2 型らい反応の診断の根拠とさえな る。まったく無効であった場合は、2型らい反応 でない可能性が高いので、1 型らい反応などほか の疾患を鑑別する。

症状の軽快に合わせて減量してゆく。その減量 方法は、ステロイドの減量ほどの注意深い漸減 (tapering) の必要はない。2 型らい反応は年余 にわたって繰り返し発症することもあるので、サ リドマイド投与量の増減は、自覚症状や他覚的所 見、および検查所見（CRP 值）の推移に合わせて 増減をする。なお現在入手可能な薬凨は $50 \mathrm{mg}$ 力 プセルと 100mg カプセルのみである。一方、血 中半減期は約 5 時間であるが、ステロイド内服薬 の例などから薬物の増減を隔日投与などの方法で 調整することは可能かもしれない。さらにサリド マイドの隔日投与についての有効性のデータがな いものの、年余にわたって内服することもあるた め、増量する場合は、例えば毎日 50mg を 50mg と 100mg を隔日に投与する（1 日目に 50mg、2 日目に $100 \mathrm{mg}$ 、 3 日目に 50mg)。減量する場合は、 例えば毎日 50mg を、50mg を隔日に投与する（2 日に $50 \mathrm{mg}$ を 1 回)。なお、サリドマイドの増減に ついての隔日投与などを実施した場合は、正確な 記録を公表すべきである。また、サリドマイドの 増減は必ず主治医が口頭と文書で指示し、患者の 自主管理に任せず、薬剤管理を確実に行う。

なお、サリドマイドの隔日投与については、多 発性骨髄腫においても少数例行われている（藤本製 薬株式会社 HP、http://www.fujimoto-pharm.co.jp/ jp/iyakuhin/thalidopdf(20110124-2).pdf の 3 ペー 
ジ)。しかし、その有効性や安全性についての報告 は無い。

b. 2 型らい反応治療において、ステロイド内 服がすでに始まっている症例での、サリドマイド の投与に関して：通常、サリドマイドとステロイ ド内服薬との併用は不要である。

2 型らい反応の診断がついたが、もしサリドマ イドの入手が遅れる場合には、ステロイド内服薬 の投与を始める。その後にサリドマイドが入手さ れれば、サリドマイドに切り替えを試みる。一方 でステロイド内服薬の漸減を通常の方法に準じて 行うが、2 型らい反応はサリドマイドによってコ ントロールされているはずなので、ステロイド内 服薬の漸減は急激な低下による副腎皮質不全を生 じないように行う。

ステロイド内服薬の漸減の過程で、らい反応の 症状の増悪や再燃を認めた場合は、サリドマイド の使用量を増量する。

c．日本におけるサリドマイド使用例について： わが国では、ハンセン病の新発生数が少ないが、 最近 5 年間（2005 2009 年）に2 型らい反応の 治療にサリドマイドを用いた症例（15 例）の集計 が日本ハンセン病学会によってなされている（表 3)。この集計は多施設による記録であり治療方針 に差があるものの、わが国におけるサリドマイド の使用成績としてよい。 サリドマイドの一日使用量は、100mg/日ない し 50mg/日である（表 3 ）。日本人の場合は欧米 人に比べて少ない量で、症状のコントロールが十 分に得られていると考えられる。使用期間は平均 2 年 5 ケ月と長期間内服を必要としている。なお、 サリドマイドの効果は主治医の判定である。

$\mathrm{d}$. サリドマイドの投与上限量に関して：サリ ドマイドの投与上限量は、欧米では $300 \mathrm{mg} /$ 日と しているが、コントロール不能の場合 $400 \mathrm{mg} /$ 日 まで許容されている。わが国でもそれに準じて投 与上限は 400mg/日までとしている。なお、日本 での投与上限 (400mg/日) は、大柄な在日外国 人でコントロール不能の患者にのみ使用すべきで、 日本人患者については $300 \mathrm{mg} /$ 日を投与上限とす ベきである。

e. サリドマイド投与中の抗ハンセン病薬の使 用について：らい反応の治療にあたっては、基本 的には投与中の抗ハンセン病薬を継続しながら、 らい反応の治療も行う。その理由は、らい反応の 原因はらい菌の存在であるので、次に起こり得る らい反応の予防のためにも、早期に原因となる菌 の排除が望ましいからである。また、一度抗ハン セン病薬を中止すると、患者の心理的なもの、つ まり、抗ハンセン病薬を服用することでらい反応 が起こった、という思い込みで、抗ハンセン病薬 の再使用を拒否することが往々にあり、原疾患の

表 3 日本国内患者別 サリドマイド使用実態

\begin{tabular}{|c|c|c|c|c|c|c|c|c|c|c|}
\hline 番号 & 年代 & 性別 & 国籍 & 病型 & $\begin{array}{l}\text { サリトママイト以外の } \\
\text { らい反応の治療 }\end{array}$ & \begin{tabular}{|l|} 
サリドマイド \\
使用期間 \\
\end{tabular} & $\begin{array}{c}\text { サリドマイド } \\
\text { 最大使用量 }\end{array}$ & $\begin{array}{l}\text { サリドマイド } \\
\text { 投与総量 }\end{array}$ & \begin{tabular}{|c|} 
サリドマイド \\
の効果 \\
\end{tabular} & 副作用 \\
\hline 1 & 50歳代 & 男 & 日本 & BL/MB & $\begin{array}{l}\text { シクロスポリン,PSL,CLF, } \\
\text { イムラン }\end{array}$ & 4ヶ月 & $300 \mathrm{mg} /$ 日 & $8.3 \mathrm{~g}$ & なし & $\begin{array}{l}\text { 深部静脈血栓 } \\
\text { 症、肺塞栓症 }\end{array}$ \\
\hline 2 & 40歳代 & 男 & フィリピン & $\mathrm{LL} / \mathrm{MB}$ & PSL,CLF & 7ヶ月 & $100 \mathrm{mg} /$ 日 & 約 $5.8 \mathrm{~g}$ & 有効 & なし \\
\hline 3 & 70歳代 & 男 & 日本 & $\mathrm{LL} / \mathrm{MB}$ & PSL,CLF & 2年10ヶ月 & $100 \mathrm{mg} /$ 日 & 約 $36 \mathrm{~g}$ & 有効 & なし \\
\hline 4 & 20歳代 & 女 & フィリ & LL/MB & $\begin{array}{l}\text { ヒドロコルチゾン静注、 } \\
\text { PSL,CLF }\end{array}$ & $\begin{array}{l}1 \text { 年3ヶ月 } \\
\text { (継続中) }\end{array}$ & $100 \mathrm{mg} /$ 日 & $\begin{array}{l}\text { 約15g } \\
\text { (継続中) }\end{array}$ & 有効 & 不明 \\
\hline 5 & 60歳代 & 男 & 日本 & LL/MB & PSL,CLF & 4年9ヶ月 & $100 \mathrm{mg} /$ 日 & 約43g & やや有効 & 不明 \\
\hline 6 & 30歳代 & 男 & ブラジル & $\mathrm{LL} / \mathrm{MB}$ & PSL,CLF & 10ヶ月 & $100 \mathrm{mg} /$ 日 & $13 g$ & 有効 & 便秘 \\
\hline 7 & 70歳代 & 男 & 日本 & $\mathrm{LL} / \mathrm{MB}$ & CLF & 4ヶ月 & $50 \mathrm{mg} /$ 日 & $4.6 \mathrm{~g}$ & 有効 & なし \\
\hline 8 & 80歳代 & 男 & 日本 & $\mathrm{LL} / \mathrm{MB}$ & なし & 5ヶ月 & $100 \mathrm{mg}$ /日 & $11.2 \mathrm{~g}$ & 有効 & なし \\
\hline 9 & 70歳代 & 男 & 日本 & $\mathrm{LL} / \mathrm{MB}$ & PSL,CLF & 6年8ヶ月 & $100 \mathrm{mg} /$ 日 & 約 $95 \mathrm{~g}$ & 有効 & なし \\
\hline 10 & 70歳代 & 男 & 日本 & $B L-L L / M B$ & なし & 5年6ヶ月 & $100 \mathrm{mg} /$ 日 & 約 $85.5 \mathrm{~g}$ & 有効 & なし \\
\hline 11 & 70歳代 & 女 & 日本 & $\mathrm{BL}-\mathrm{LL} / \mathrm{MB}$ & なし & 1年7ヶ月 & $50 \mathrm{mg} /$ 日 & 約 $1.5 \mathrm{~g}$ & 不明 & なし \\
\hline 12 & 80 歳代 & 男 & 日本 & $B L-L L / M B$ & なし & 2年9ヶ月 & $75 \mathrm{mg}$ /日 & 約3.25g & 有効 & なし \\
\hline 13 & 50歳代 & 男 & 日本 & LL/MB & PSL,CLF,NSAIDs & 3年6ヶ月 & $100 \mathrm{mg} /$ 日 & 約3.35g & 有効 & なし \\
\hline 14 & 80歳代 & 男 & 日本 & $\mathrm{BL}-\mathrm{LL} / \mathrm{MB}$ & なし & 5年 & $50 \mathrm{mg} /$ 日 & 約 $101.4 \mathrm{~g}$ & 有効 & なし \\
\hline 15 & 70歳代 & 男 & 旦本 & LL/MB & CLF,NSAIDs & 1年 & $100 \mathrm{mg}$ /日 & 約 $46.6 \mathrm{~g}$ & 有効 & なし \\
\hline
\end{tabular}

$<$ 薬剂略号>

CAM:クラリスロマイシン CLF:クロファジミン NSAIDs:非ステロイド性抗炎症薬ＰSL:プレドニゾロン

<病型 略語>

BL:ハンセン病BL型ＬL:ハンセン病LL型 MB:多菌型 
治療が不可能となることがあるからである。

f ．2 型らい反応のサリドマイド以外の治療薬： 何らかの事情でサリドマイド治療が困難な場合、 ステロイド内服薬の全身投与も有効である。投与 量は $0.5 \sim 1 \mathrm{mg} / \mathrm{kg} /$ 日で開始する。欧米では、1 〜 $2 \mathrm{mg} / \mathrm{kg} /$ 日の量が必要とされているが、わが国 では、 $0.5 \sim 1 \mathrm{mg} / \mathrm{kg} /$ 日の量で 2 型らい反応のコ ントロールは通常可能である。減量方法は通常の 漸減方法と同様であるが、とくに少量になってか らは漸減の間隔をのばす方がよい。

少数の ENL が散発するだけの時期になれば、ス テロイド内服薬の全身投与を中止してよい。しか し、BI の高い患者では年余にわたって2 型らい反 応の消長をくりかえすことがあり、ステロイド内 服薬離脱が困難になる。 g. 2 型らい反応に打ける眼症状の治療 : 虹彩 毛様体炎や（上）強膜炎に対するサリドマイド単 独治療の有効性は不明である。そのためサリドマ イドとステロイド薬の局所投与 (点眼) の併用が 必要である。点眼で消炎しない場合はステロイド の結膜下注射・全身投与を追加する。同時に瞳孔 管理と眼圧管理も行う。

h. 患者のケアについて : 2 型らい反応は年余 にわたり服薬指導の厳しいサリドマイド、副反応 の起こりやすいステロイド内服薬を長期間内服し、 さらに全身の痛みや発熱、失明の不安などもある ため精神的なケア（カウンセリング、抗うつ剤投 与等) が重要である。

4. クロファジミンについて

クロファジミン (clofazimine: CLF, B663（ラ

\section{表4サリドマイドの副作用}

重大な副作用

1. 催奇形性(サリドマイド胎芽病)

2. 深部静脈血栓症

3. 未梢神経障害(手足のしびれ、うずき、痛み、灼熱感等)

4. 骨髄機能抑制(好中球減少、白血球減少、赤血球減少、血小板減少等)

5. 感染症(肺炎等の重篤な感染症)

6. 消化管穿孔

7. 虚血性心疾患

8. 皮膚粘膜眼症候群(Stevens-Johnson 症候群)、中毒性表皮壊死症(Lyell 症候群)

9. 嗜眠状態、傾眠、鎮静

10. 痓攣

11. 起立性低血圧

12. 心障害(不整脈、徐脈等)

13. 甲状腺機能低下症

主な副作用(国内第 II 相臨床試験)

1. 便秘

2. 眠気

3. 口内乾燥

4. しびれ

5. 発疹・皮疹

6. 好中球減少(臨床検查值の異常変動)

7. 白血球減少(臨床検查值の異常変動) 
ンプレン®、サンド薬品)) は、ハンセン病の標準 的治療であるWHOの多剂併用療法 (multidrug therapy、MDT）の一剂として、リファンピシン (rifampicin: RFP)、ダプソン (dapsone、DDS) と ともに用いられている。MDT の場合は、CLFを月 1 回 300mg、他の 27 日間は 50mg/日内服する。 副作用に、赤褐色調の皮膚の色素沈着、とくに皮 疹部は黒褐色調になる。また、皮膚乾燥もよく知 られている。マクロファージ内にCLFを蓄積する ことと、抗炎症作用を示すことで 2 型らい反応に も緩徐に有効性を示すと考えられる。

CLF は 2 型らい反応を抑制する効果がある。虹 彩毛様体炎を抑制するともいわれている。したがっ て、2 型らい反応が生じた場合に、あるいは神経 痛などの症状があり、らい反応も疑われる様な時 期に CLF の投与を行うことがある(表 3)。しかし、 ステロイド内服薬やサリドマイドに認められるよ うな明らかな抗 2 型らい反応作用はないと考えら れる。通常 1 日量 50mg/日を 100mg/日（外国で は最大 $200 \mathrm{mg} /$ 日処方する例もあり）にすること で、ステロイド内服薬やサリドマイドの投与量の 減少を試みる。ただし $100 \mathrm{mg} /$ 日の投与で色素沈 着が顕著になり、まれに下痢・腹痛もおこり患者 が投与を嫌うことがある。

\section{2型らい反応に対するその他の治療薬}

TNF- $\alpha$ の産生を抑制する薬剤や生物製剂、免疫 抑制薬のサイクロスポリン $25-27)$ などが期待されて いる。

\section{6）サリドマイドの副作用}

重大な副作用として、催奇形性、深部静脈血栓症、 未梢神経障害、骨髄機能抑制、感染症、消化管穿孔、 虚血性心疾患、皮膚粘膜眼症候群、中毒性表皮壊 死症、嗜眠状態、傾眠、鎮静、痙攣、起立性低血圧、 心障害、甲状腺機能低下症などが報告されている。 また、治療抵抗性多発性骨髄腫患者における国内 第 II 相臨床試験では、主な副作用として眠気、便秘、 口内乾燥、しびれ、好中球減少、白血球減少など が認められている（表 4)。これらの副作用が発現 した場合は休薬・減量あるいは投与を中止し、適 切な処置を行う必要がある。なお、末梢神経障害 にはビタミン $\mathrm{B}_{6}$ が有効とされている ${ }^{29) 。}$

\section{7）おわりに}

サリドマイドはハンセン病 2 型らい反応に著効 するが、重大な副作用も示す。2 型らい反応を診 療する医師は、サリドマイドを使用するにあたっ ては、薬についての十分な知識をもって使用する ことで患者の症状の改善に向かわせることができ る。サリドマイドの適正な使用とともに、さらに 安全性と有効性の高い薬剤の登場を期待したい。

\section{文 献}

1 ) 中嶋弘、長尾榮治、尾崎元昭、石井則久: ハンセン病診断・治療指針. pp1-48, 厚生省, 1997.

2 ) 熊野公子：らい反応について. 日ハンセン病 会誌 71: 3-29, 2002.

3 ）多発性骨髄腫に対するサリドマイドの適正使 用ガイドライン (平成 $15 \cdot 16$ 年度厚生労働 省関係学会医薬品等適正使用推進事業) 日本 臨床血液学会医薬品等適正使用評価委員会

4 ) Sheskin J: Thalidomide in the treatment of lepra reactions. Clin Pharmacol Ther 6: 303306, 1965.

5 ) Singhal S, Mehta J, Desikan R, Ayers D, Roberson P, Eddlemon P, Munshi N, Anaissie E, Wilson C, Dhodapkar M, Zeddis J, Barlogie B: Antitumor activity of thalidomide in refractory multiple myeloma. N Engl J Med 341: 1565-1571, 1999.

6 ) Pearson JM, Vedagiri M : Treatment of moderately severe erythema nodosum leprosum with thalidomide- a double-blind controlled trial. Lepr Rev 40, 111-116, 1969.

7 ) Sheskin J, Convit J: Results of a double blind study of the influence of thalidomide on the lepra reaction. Int J Lepr 37, 135-146, 1969.

8 ) Iyer CG, Languillon J, Ramanujam K, TarabiniCastellani G, De las Aguas JT, Bechelli LM, Uemura K, Martinez Dominguez V, Sundaresan T: WHO co-ordinated short-term doubleblind trial with thalidomide in the treatment 
of acute lepra reactions in male lepromatous patients. Bull World Health Organ 45: 719 732, 1971.

9 ) Waters MF: An internally-controlled double blind trial of thalidomide in severe erythema nodosum leprosum. Lepr Rev 42, 26-42, 1971.

10) Iyer $C G$, Ramu G: An open trial with clofazimine in the management of recurrent lepra reaction using thalidomide as a control drug. Lepr India 48, 690-694, 1976.

11) Villahermosa LG, Fajardo TT Jr, Abalos RM, Balagon MV, Tan EV, Cellona RV, Palmer JP, Wittes J, Thomas SD, Kook KA, Walsh GP, Walsh DS: A randomized, double-blind, double-dummy, controlled dose comparison of thalidomide for treatment of erythema nodosum leprosum. Am J Trop Med Hyg 72: 518 526, 2005.

12) Sales AM, de Matos HJ, Nery JA, Duppre NC, Sampaio EP, Sarno EN: Double-blind trial of the efficacy of pentoxifylline vs thalidomide for the treatment of type II reaction in leprosy. Braz J Med Biol Res 40: 243-248, 2007.

13) Kaur I, Dogra S, Narang T, De D: Comparative efficacy of thalidomide and prednisolone in the treatment of moderate to severe erythema nodosum leprosum: a randomized study. Australas J Dermatol 50: 181-185, 2009.

14) Van Veen NH, Lockwood DN, Van Brakel WH, Ramirez J Jr, Richardus JH: Intervention for erythema nodosum leprosum. A Cochrane review. Lepr Rev 80: 355-372, 2009.

15) Zeldis JB, Williams BA, Thomas SD, Elsayed ME: S.T.E.P.S.: A comprehensive program for controlling and monitoring access to thalidomide. Clin Ther 21: 319-330, 1999.

16) Parida SK, Grau GE, Zaheer SA, Mukherjee R: Serum tumor necrosis factor and interleukin 1 in leprosy and during lepra reactions. Clin Immunol Immunopathol 63: 23-27, 1992.

17) Sampaio EP, Kaplan G, Miranda A, Nery JA, Miguel CP, Viana SM, Sarno EN: The influence of thalidomide on the clinical and immunologic manifestation of erythema nodosum leprosum. J Infect Dis 168: 408-414, 1993.

18) Chaudhary SD, Sen R, Jain VK, Dixit VB: Leukemoid reaction in erythema nodosum leprosum in a leprosy patient. Indian J Lepr 60: 572-576, 1988.

19）後藤正道、野上玲子、烟野研太郎、岡野美子、 石井則久、儀同政一、石田 裕、尾崎元昭： ハンセン病治療指針 第 2 版. 日ハンセン病 会誌 75: 191-226, 2006.

20) Latapi-Contreras F, Caire-Loyer P, FloresAlonso O, Flores-Romero RM: Bacterial sampling using lymph node puncture-aspiration. A study of 50 patients with leprosy. Acta Leprol 6: 7-16, 1988.

21) Parikh DA, Ganapati R, Revankar CR: Thalidomide in leprosy: study of 94 cases. Indian J Lepr. 58: 560-566, 1986.

22）菅谷和江、新井春枝、藤田裕介、和泉眞蔵： 熱瘤を生じたハンセン病 LLP 型の 1 例．皮膚 科の臨床 $39: 1689-1693,1997$.

23）杉浦典子、松本佳子、伊藤由佳、倉知貴志郎、 小塚雄民、河原邦光、倉田明彦、伊藤利根太 郎、松岡正典、小林和夫、矢島幹久、和泉眞蔵： らい性結節性紅斑（ENL）を伴った LL 型ハン セン病の 1 例. 皮膚科紀要 $93: 658,1998$.

24) Kawakami T, Tsutsumi Y, Mizoguchi M, Ishii N, Soma Y: Leprosy with hepatic involvement. Int J Dermatol 46: 348-349, 2007.

25) Uyemura K, Dixon JF, Wong L, Rea TH, Modlin RL: Effect of cyclosporine A in erythema nodosum leprosum. J Immunol 137: 36203623, 1986.

26) Lockwood DN: The management of erythema nodosum leprosum: current and future options. Lepr Rev 67: 253-259, 1996.

27) Chin-A-Lien RA, Faber WR, Naafs B: Cyclosporin A treatment in reversal reaction. Trop Geogr Med 46: 123-124, 1994.

28) Singhal S, Mehta J: Thalidomide in cancer. Biomed Pharmacother 56: 4-12, 2002. 


\section{サリドマイド被害者からのメッセージ}

私たちは薬害により障害を持って生まれ、今も日々の生活に様々な不自由を感じながら生きて います。この薬がなければ、私たちは被害を受けることはありませんでした。そのような恐ろし い薬を二度と使ってほしくありません。

しかし、サリドマイドにより救われる人がいるなら、䛊りなく使用されることを念じます。薬 そのものが悪い訳ではなく、過去の出来事を知らず、充分な知識がないまま使用する側に責任が あると思います。繰り返される薬害事件で製薬企業や役人が頭だけ下げる光景はもう見たくあり ません。同じ過ちを繰り返さないために、ひとりでも多くの人に関心を持ってもらいたい。義務 教育で教え、すべての人が「自分の身にも起こり得る出来事」として認識してほしいと思います。

サリドマイドを使うのであれば、厳しいルールの下での使用に限定すべきです。医療機関・医 師・薬剤師そしてサリドマイドを必要とする患者・家族のみなさんなど、この薬に関わるすべて の人は正しい判断をしてください。ルールが守られないならば、全面禁止でない限り再発防止は できないと思います。こんな悲劇は自分たちだけでたくさんです。

私たちはサリドマイドによる新たな被害が発生しないことを願い、引き続きサリドマイドの適 正使用について見守っていきたいと考えています。

（財）いしずえ（サリドマイド福祉センター） 


\title{
Japanese guideline on thalidomide usage in the management of erythema nodosum leprosum
}

\author{
Norihisa ISHII ${ }^{* 1)}$, Yutaka ISHIDA ${ }^{2)}$, Yoshiko OKANO ${ }^{3)}$, Motoaki OZAKI ${ }^{4)}$, \\ Masaich GIDOH $^{1}$, Kimiko KUMANO $^{5}$, Masamichi GOTO ${ }^{6}$, Reiko NOGAMI ${ }^{7}$, \\ Kentaro HATANO ${ }^{3)}$, Akatsuki YAMADA ${ }^{8)}$, Rie Roselyne YOTSU ${ }^{9)}$
}
1) Leprosy Research Center, National Institute of Infectious Diseases, Tokyo, Japan
2) Amakusa City Ushibuka Citizens' Hospital, Kumamoto, Japan
3) National Sanatorium Oku-Komyo-En, Okayama, Japan
4) Department of Dermatology, Kyoto University Graduate School of Medicine, Kyoto, Japan
5) Hyogo Cancer Center, Hyogo, Japan
6) National Sanatorium Hoshizuka Keiaien, Kagoshima, Japan
7) National Sanatorium Kikuchi Keifuen, Kumamoto, Japan
8) National Suruga Sanatorium, Shizuoka, Japan
9) Department of Dermatology, National Center for Global Health and Medicine, Tokyo, Japan

[Received: 13 April, 2011 / Accepted: 25 April, 2011]

\begin{abstract}
Key words : erythema nodosum leprosum (type 2 reaction), guideline, Hansen's disease (leprosy), thalidomide, Thalidomide Education and Risk Management System $\left(\right.$ TERMS $^{\circledR}$ )
\end{abstract}

Treatment of erythema nodosum leprosum (ENL, type 2 reaction) using thalidomide provides effective alternative choice to steroid therapy. Yet, the Japanese National Health Insurance approves thalidomide prescription only for the treatment of multiple myeloma under the Thalidomide Education and Risk Management System $\left(\right.$ TERMS $^{\circledR}$ ). Benefit of thalidomide therapy for patients with ENL is already an established fact based on various reports from other countries, but limited experiences and standards in Japan have hindered application of the medication to our patients. This led us to compose a local guideline. Based on and following the TERMS ${ }^{\circledR}$, we suggest starting thalidomide from $50-100 \mathrm{mg} /$ day and then onwards adjusting the dose according to the symptoms of each patient, not to exceed the maximum recommended dose of $300 \mathrm{mg} /$ day, for the treatment of ENL.

\footnotetext{
*Corresponding author :

Leprosy Research Center, National Institute of Infectious Diseases

4-2-1, Aoba-cho, Higashimurayama-shi, Tokyo 189-0002 Japan.

TEL : +81-42-202-6003 FAX : +81-42-391-8210

E-mail : norishii@nih.go.jp
} 